\title{
IDENTIFICATION OF OCEANOGRAPHIC PARAMETERS FOR DETERMINING PELAGIC TUNA FISHING GROUND IN THE NORTH PAPUA WATERS USING MULTI-SENSOR SATELLITE DATA
}

\author{
VINCENTIUS SIREGAR ${ }^{1}$ AND HAROLD JOPPIE DAVIDO WAAS ${ }^{2)}$ \\ "SEAMEO B1OTROP, Bogor, Indonesia \\ ${ }^{2>}$ Faculty of Fisheries, University ofPattimura, Ambon, Indonesia
}

\begin{abstract}
The North Papua waters as one of the important fishing grounds in the world contribute approximately $75 \%$ of world production of pelagic tunas. These fishing grounds are still determined by hunting method. This method is time consuming and costly. However, in many areas determination of fishing ground using satellited data lias been applied by detecting the important oceanographic parameter of the presence of fish schooling such as, sea surface temperature and chlorophyl. Mostly these parameters are used integratedly. The aim of this study is to assess the important oceanographic parameters detected from multi-sensor satellites (NOAA/AVHRR, Seawifs and Topex Poisedon) for determining fishing ground of pelagic tunas in the North Papua waters at east season. The parameters include Sea Surface Temperature (STT), chlorophyl-a and currents. The availability of data from optic sensor (Seawifs: chl-a and AVHRR: Thermal) is limited by the presence of cloud cover. In that case, Topex Poseidon satellite data can be used to provide the currents data. The integration of data from multi-sensors increases the availability of the oceanographic parameters for prediction of the potential fishing zones in the study area.
\end{abstract}

Key words : Identification, oceanographic parameter, sea surface-temperature, chlorophyl-a, multi sensors, pelagic tuna, North Papua-waters

\section{INTRODUCTION}

The North Papua Waters in West Pacific is one of the important fishing grounds for Tuna in the world, beside the East Pasific waters, Japan and west coast of Africa. It has contributed $75 \%$ of world production of Skipjack (Katsuwonus pelamis) and yellow fin (Thunnus albacares) (Lewis and Williams 2001). The fishing activities of local fishermen and the fishing fleet of a national company in this area is characterized by hunting method, eventhough actually using echo-sounder to detect fish schools of tunas. They use natural features such as birds, floating woods, shools of dolphines and whales to locate the tuna schools. This feature having been in use since longtime, has convinced experts to consider as an indicator of the existence of pelagic tunas. However, this method is practically inefficient because it is time consuming and costly.

According to previous researches, it is known that the presence of tunas in the waters is possible due to the availability of food in the area, which is indirectly trigged by the occurrence of thermal front, current (divergent and convergent) and eddys (Dwivedi 2001 ; Lehodey 2003). In line with the development of remote 
sensing technology, these oceanography parameters, in real time, can be detected by sensors of satellite remote sensing.

This study is intended to determine oceanography parameters as a key factor in the detection of potential fishing grounds of the Skipjack and Yellowfm tuna in north Papua waters in west Pasific using multi-sensors of satellite data.

\section{MATERIALS AND METHODS}

The study was conducted in the North Papua waters with coordinate $3^{\circ} 40^{\prime} \mathrm{S}-6^{\circ} 40^{\prime} \mathrm{U}$ and $130^{\circ} \mathrm{E}-142^{\circ} \mathrm{E}$, from August to October 2003 (Figure 1). Satellite data used to identify oceanographic parameters for determining Skipjack and Yellowfm tuna fishing ground are collected from multi-sensors satellite (NOAA/AVRR, Seawifs and Topex Poisedon).

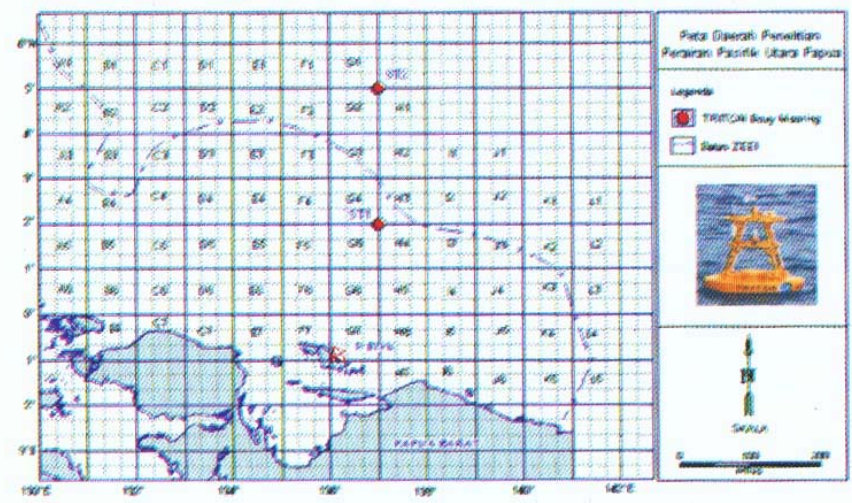

Figure 1. Study area and location of TRITON Mooring Bouy

Local Area Coverage (LAC) of NOAA/AVHRR data received from LAP AN (Indonesian Agency of Aerospace), Biak ground station are used to map Sea Surface Temperature (SST) distribution using the equation of Me Millan dan Crosby (1984), as follows:

$$
\begin{aligned}
& \text { SST }=(\text { TW4 }+2.702 *(\text { TW4 }- \text { TW5 })-0.582)-273^{\circ} \mathrm{C} \\
& \text { TW4 }=\text { Temperature brigthness of band } 4 \\
& \text { TW5 }=\text { Temperaure brightness of band } 5
\end{aligned}
$$

SST data derived from NOAA/AVHRR were validated using TRITON Mooring Bouy data at the position of $\left(02^{\circ} \mathrm{N} ; 137^{\circ} \mathrm{E}\right),\left(05^{\circ} \mathrm{N} ; 137^{\circ} \mathrm{E}\right)$. These mooring data were received from the website 
http://www.pmel.noaa.gov/tao/jsdiSPLay at the same time with satellite data. T-test is performed according to Steel and Torrie (1989) using the equation:

$$
\begin{aligned}
\overline{\mathrm{T}} & =\left(\mathrm{X}_{1}-\mathrm{X}_{2}\right) / \mathrm{s} \ldots \ldots \ldots \ldots \ldots \ldots \ldots \ldots \ldots \ldots \ldots \ldots \ldots \ldots \ldots \ldots \\
\overline{\mathrm{X}}_{1} & =\mathrm{t} \text {-distribution } \\
\overline{\mathrm{X}}_{2} & =\text { SST (average) of NOAA-17/AVHRR } \\
\mathrm{s} & =\text { standard deviation }
\end{aligned}
$$

The thermal front derived from SST is analysed using the formula proposed by Meaden and Chi (1996), as follows:

$$
\begin{aligned}
& \triangle \mathrm{SST}=(\mathrm{SST}-)+(\mathrm{SST}+) /(\mathrm{SST} s) ? 1 \mathrm{C}^{\circ} \\
& \triangle \mathrm{SST}=\mathrm{SST} \text { gradient at thermal boundary } \\
& (\mathrm{SST}-)=\text { pixel value of SST at left side of thermal boundary } \\
& (\mathrm{SST}+)=\text { pixel value of SST at right side of thermal boundary } \\
& (\mathrm{SST})=\text { pixel value of SST at thermal boundary }
\end{aligned}
$$

From the equation above, a method to determine thermal front zone is established as follows :

$$
\begin{array}{ll}
\$^{*} & =\text { If }(? \mathrm{SSTi}, \mathrm{I}, 1,0) \ldots \ldots \ldots \ldots \ldots \ldots \ldots \ldots \ldots \ldots \ldots \\
\$^{*} & =\text { area of thermal front } \\
\triangle \mathrm{SSTi} & =\text { gradient value of SST at thermal boundary } \\
1 & =\text { identity pixel area of thermal front } \\
0 & =\text { identity pixel non area of thermal front }
\end{array}
$$

Images of TOPEX POISEDON and SeaWIFS received in the form of Globale Area Coverage (GAC) from website htlp://www-ccar.Colorado.edu/ and http://seawifs.gsfc.nasa.gpy/. are utilized for current analysis (divergent, convergent and eddys), and Chlorofill-a distribution. The analysis is performed according to Pickard and Emery (1990). Meanwhile, fishing catch data are collected from the fishing fleet of Purse seiner 1025 GT(amount :15) of PT.BIAK MINA JAVA. This Purse Seiner has dimension of $1800 \mathrm{~m}$ in length and $300 \mathrm{~m}$ in width. The fishing catch data is in the form of CPUE (catch per unit of effort ton" ${ }^{1}$ per ship hour"1 $)$. 


\section{RESULTS AND DISCUSSIONS}

\section{SST validation}

Validation of SST derived from NOAA/AVHRR data using TRITON buoy data (in situ) showed that the SST from these two different systems has similar pattern with certain variations of value of the SST. This variation could happen depending on the oceanographic condition that controls the temperature structure at depth measurement (Robinson 1985). T-test (95\%) showed that there is a strong correlation $(\mathrm{R}=0.72)$ between the SST of these different systems (Figure 2). Therefore, we used this algorithm to map the distribution of SST for further analysis and discussion.

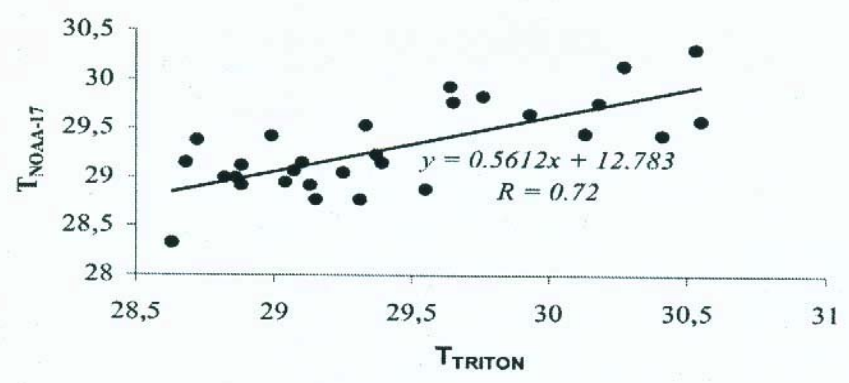

Figure 2. Relationship between SST derived from NOAA/AVHRR and TRITON Mooring Buoy data

\section{Fishing ground condition}

The oceanographic parameter of Skipjack and Yellowfm tunas fishing grounds detected from multi-satellite sensors showed that in the east season, the distribution of the fishing grounds is concentrated at warm water centroids with temperature range varying between 27.02 and $30.86^{\circ} \mathrm{C}$, except during the first week of August where the temperature is lower than before, varying between 26.64 and $27.45^{\circ} \mathrm{C}$. Low SST during this month is probably due to the appearance of equatorial upwelling which attains its peak in June-July (Vinogradov 1981), with the lowest SST detected varying from 26.62 to $26.87^{\circ} \mathrm{C}$ (Waas 2004). From this range of SST, it is presumed that the appearance of two tuna species in July and August is related with the period of their spawning season, where the ideal temperature is limited to $26^{\circ} \mathrm{C}$ (Lehodey 2003), thus this water is a good spawning ground for Skipjack and Yellowfm tuna (Loukos et al. 2003).

Chlorophyll-a (CHL-a) is an indicator of the productivity of the waters which has indirect relationship with the tuna food found at high concentration in fishing grounds every month during the period of study. The concentration of CHL-a detected varies between 0.21 and 0.35 ingm" ${ }^{3}$. The high concentration of CHL-a 
( $>0.2 \mathrm{mg} \mathrm{\textrm {m } ^ { 3 }}$ ) indicates that the presence of this phytoplankton in the waters is suitable to support or to maintain the sustainability of the development of fisheries, such as Skipjack and Yellowfin tunas (Gower 1972). Lehodey (2003) and Wcnno et al. (2001) found that there is a high concentration of CHL-a near the coastal zone of North Papua. This high concentration of CHL-a is contributed not only by the upwelling (equatorial upwelling) process which occurred in that area, but also by the river flow (e.g.Mamberamo River and Matabori River) which bring nutrient to the north Papua waters, and by Halmahera Eddies (LIPI 1992).

The surface current detected by TOPEX POSEIDON satellite in the fishing grounds of Skipjack and Yellowfin tunas is classified as South Equatorial Current (SEC) system, concentrated at $0^{\circ}-2.5^{\circ} \mathrm{N}$. The appearance of those tunas in this zone has strong relationship with the occurrence of divergent and convergent currents detected. The high concentration of phyto planktons during the equatorial upwelling at $0^{\circ}-0.5^{\circ} \mathrm{N}$, is predicted indirectly as a factor of the appearance of tunas at this system of currents. This condition confirms the hypothesis of Uda (1973) in Laevastu and Hayes (1981) that the good fishing ground for tuna is found in the system of SEC.

\section{Oceanographic parameter derived from Satellite data}

Due to cloud cover, the number of images available from optic sensor used is limited. The number of images available are thermal: 10, CHL-a distribution: 4 and currents : 12 images. Those images were used for the analysis, but in this paper the number of images presented is limited to 2 for each type of data. The important parameter analysed from the available images are described as follows :

\section{Thermal front}

Analysis of thermal front using 10 images available showed that fronts could occur and develop in the North Papua waters. The thermal front is detected from August until October 2003 in different forms and patterns. At the end of August the front is in the form of line streched from North of Monokwari towards the Northeast as long as 840 nautical miles. The position of fishing activities spread out near the thermal front in the warmest water mass. During September, the thermal front appears clearly. This front has a length varying from 550 - 920 nautical miles, move away off the waters of Monokwari towards the Northeast, forming a smaller width of meandering. Intensive fishing was found concentrated at the meandering zone, which has a role as barrier, so that the phyto planktons could not move away from the front zone (Dwivedi 2000). On the $2^{\text {nd }}$ and $11^{\text {th }}$ September (Figure 3a,b), fishing grounds were clearly found near the thermal front. This phenomenon confirms Narain's study (1993) that the high intensity of fishing occurs at the thermal front.

The thermal front still exists during the month, move and change its form following the currents pattern. High concentrations of phyto planktons occur at the front due to two different water masses (warm and cold) and divergent currents (Shixing et al. 1993). These currents can be seen from image of TOPEX POSEIDON at the same date of acquisition. Along the thermal front, a high 


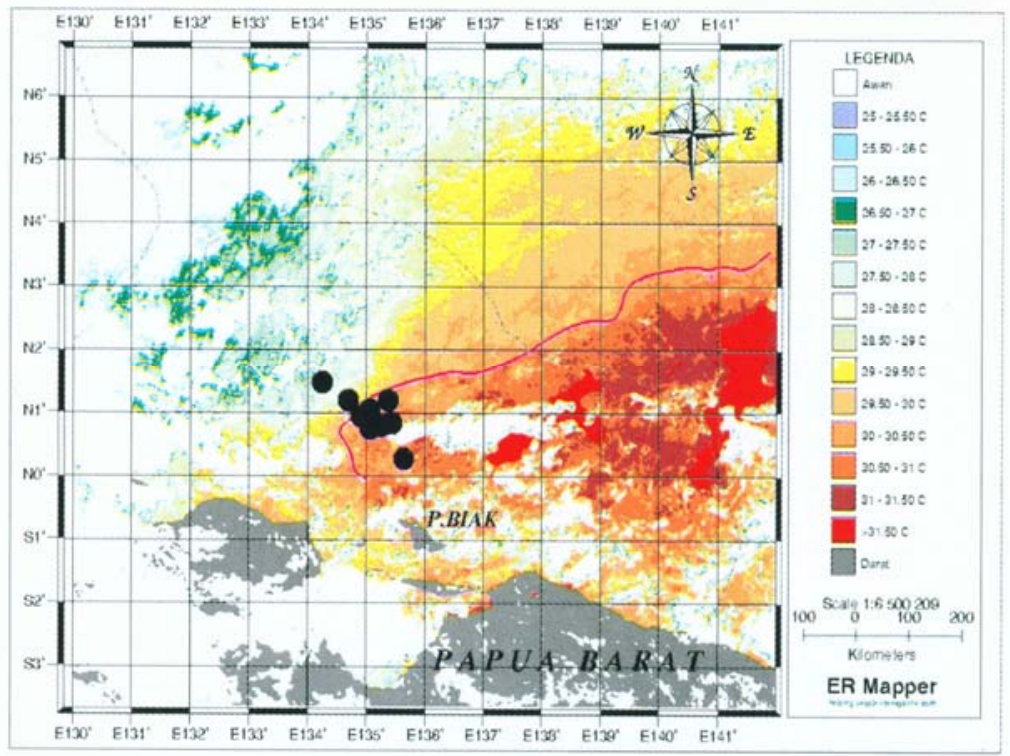

(a) 2 September 2003

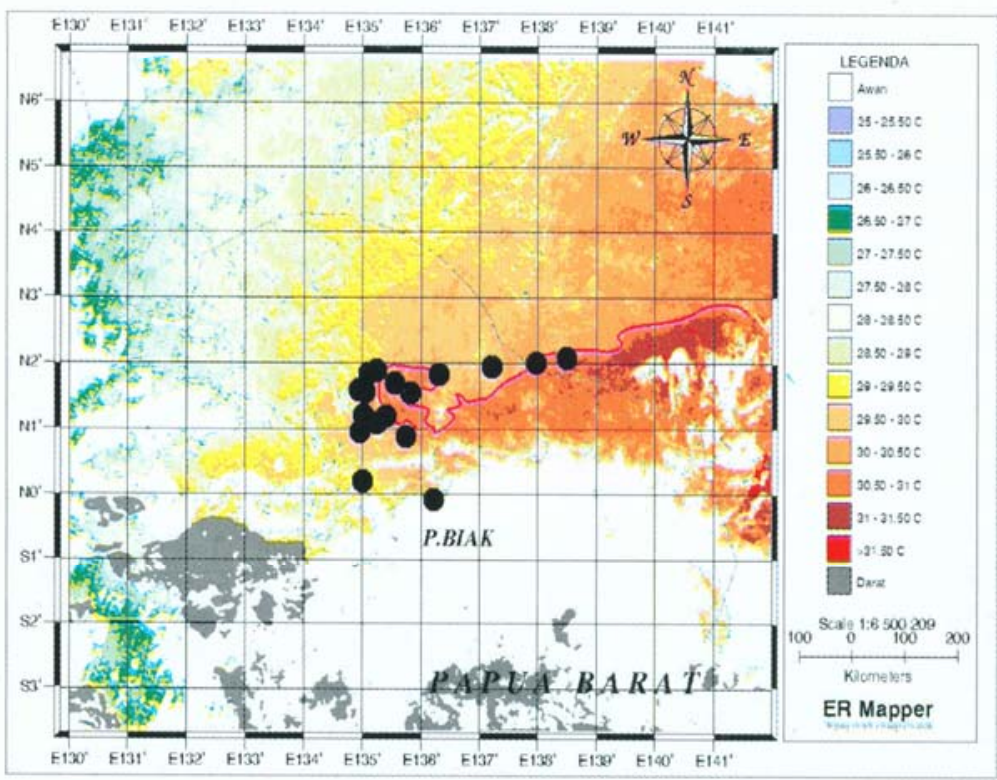

(b) 11 September 2003

Figure 3. Thermal front detected from NOAA/AVHRR on 2 September and 11 September 2003 
concentration of CHL-a was recorded, and at the same time, convergent current and eddys were taken place.

In October, the thermal front has different pattern compared to the front of the previous month. This front forms cold water pockets with a width of $\pm 9.02-71.35$ n.mile square and surrounded by warm water mass from the Pacific Ocean. The position of the fishing ground was generally concentrated outside of the thermal front zone. In the front zone, strong divergent current and eddys were taken place so that the cold water mass was spreading out following the direction of the current

\section{Chlorophyll-a Distribution}

During August and September, the images of the area were not realy clear due to the cloud cover. However, from those images and by plotting the area of fishing activities, it showed that Skipjack and Yellowfin tunas were found in the area of higher CHL-a concentration and along the front (Figure 4). In August the CHl-a front is not clear. Meanwhile, in October the images of CHL-a is not available.

In most of the cases, in order to locate accurately the potential fishing grounds, the images of CHL-a distribution and sea surface temperature are used integratedly. This method could be proposed as an important technique for identifying the potential fishing ground. The method also provides indirect information on the horizontal mixing of water masses, which contributes to high productivity or high concentration of phyto plankton (CHL-a) in the waters (Dwivedi 2000). In this study, these images from different sensor optics (NOAA/AVHRR and SeawiFs) are also used together.

\section{Currents}

Currents (convergent, divergent and eddies) are specific oceanographic parameters in the North Papua waters. These parameters play an important role in the development of thermal front, the distribution of water mass and the concentration of chlorophyll-a in the area. Together, the convergent and divergent these currents are favorable for the development of marine organisms. The area with divergent currents has high productivity, and convergent current forms a mechanism of phyto plankton aggregation at the front of currents. Meanwhile, eddies as the result of moving cycle (form a ring) of the water masses increase the intensity of vertical mixing of the waters followed by upwelling which occurs at the outer side of the ring, triggering the increase of water mass productivity (Dwivedi 2000).

According to Mean and Lazier (1990), currents in the study area are classified into a). SEC (South Equatorial Current) with direction to the west b). NECC (North Equatorial Counter Current) is a narrow current with the direction to the east, and c). EUC (Equatorial Upwelling Current) is subsurface water current with the direction to the east. The dynamic of these currents is due to the Coriolis force, which effects divergent and convergent currents along the borders of the currents in different directions. These currents occurred intensively in the Papua waters. The illustration 


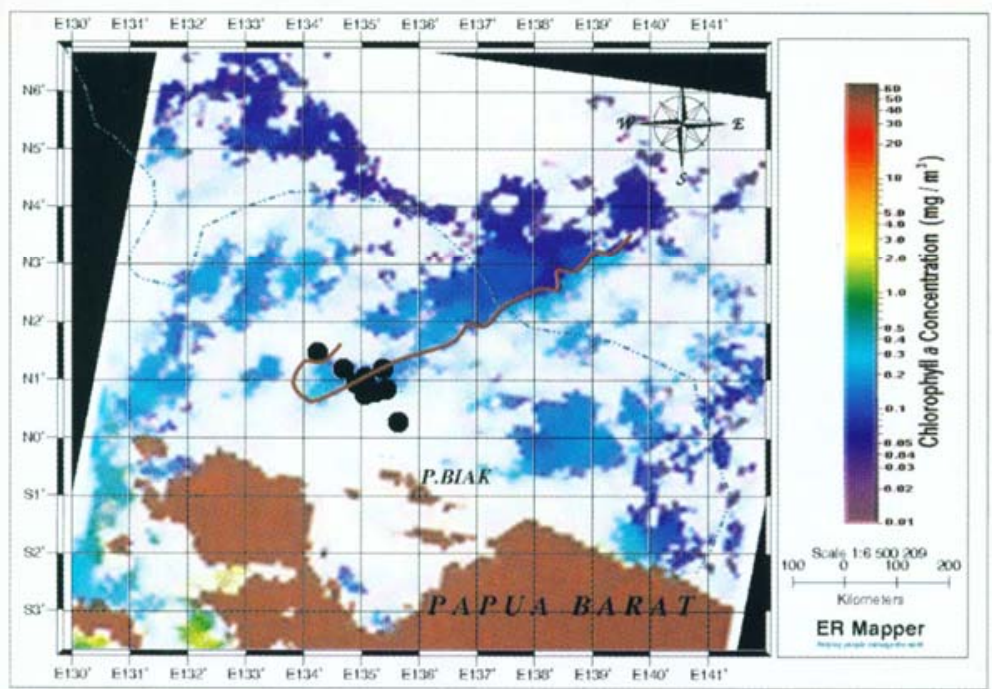

(a) 2 September 2003

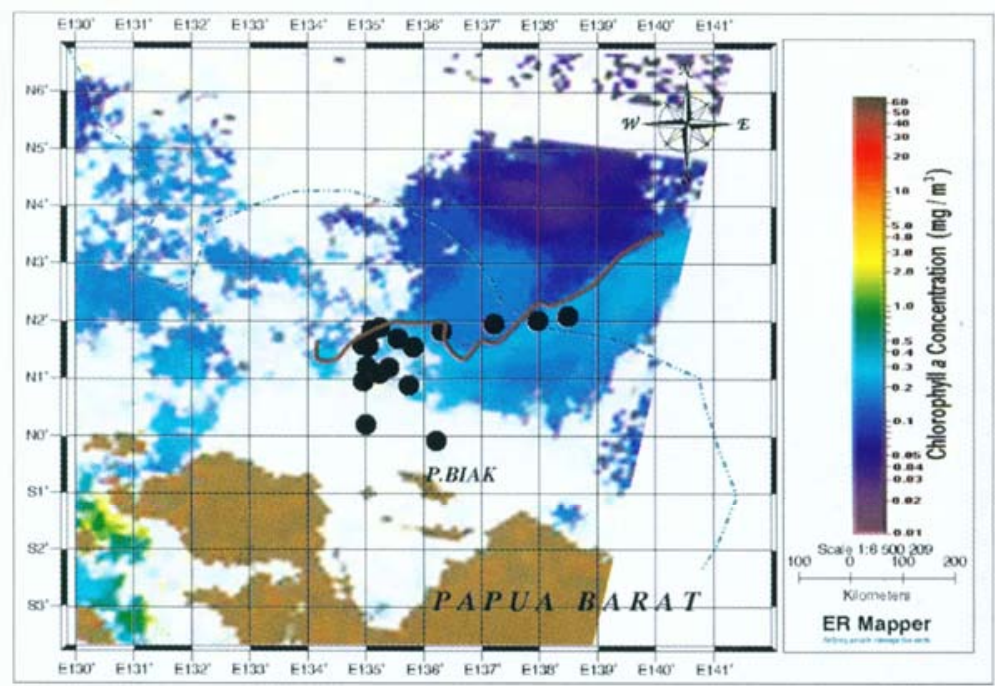

(b) 11 September 2003

Figure 4. CHL-a front detected from Seawifs and the position of pelagic tunas fishing ground on 2 and 11 September 2003. 
of this mechanism is shown in Figure 5: (a.l) currents in the northern hemisphere have oposite direction, west-east; (a.2) shows the effect of Corriolis force, the currents are divergent and the subsurface water upwell replaces the surface water as a result. This mechanism occurs in the system current of NEC (Northern Equatorial Current) and NECC; (b.l) showing the convergent current as the result of NECC and SEC encounter; (c.l) in the equator, SEC with direction towards the west will create divergent currents, inversly, with directions towards the east will create convergent currents (d. 1 dan d.2).

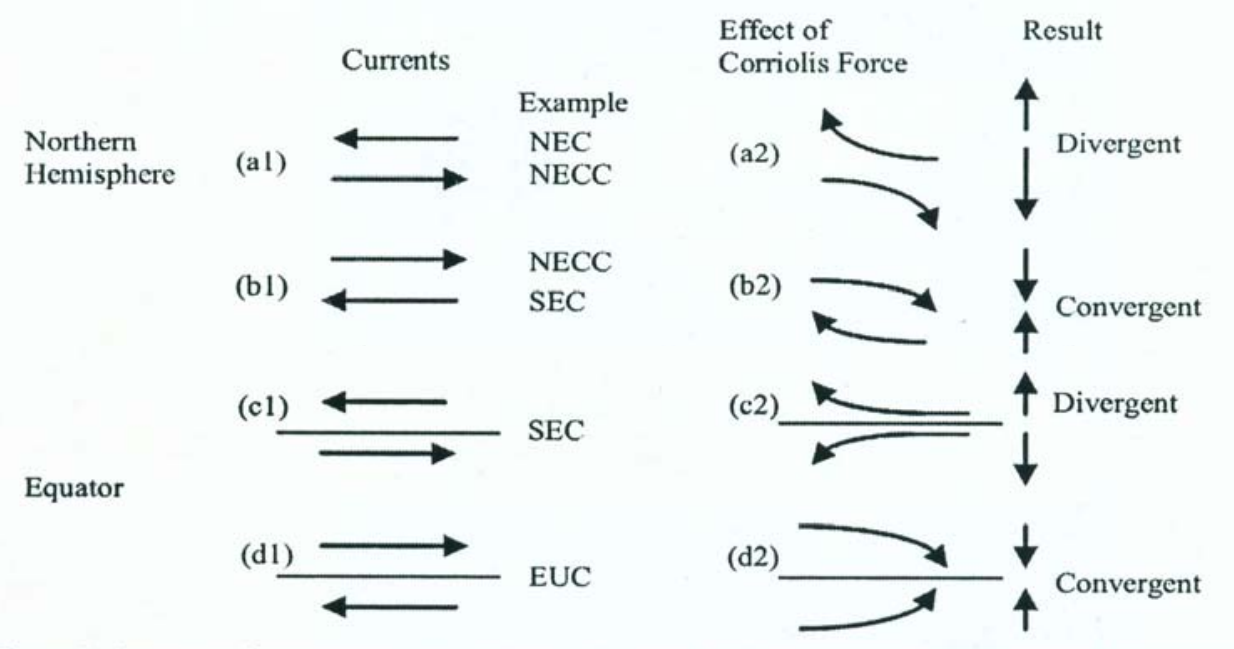

Figure 5. Currents of convergent and divergent as a result of Corriolis force (Pickard and Emery1990)

The analysis of fishing ground based on available data set of Topex Poisedon (augustOctober) showed that the pelagic tunas are mostly catched in all types of current such as divergent, convergent and eddies . In August, most of the fishing grounds were found at the outer ring of eddys and divergent current (Fig 6 a). At the end of the month, most of the fishing grounds were only found at the convergent current system. In September and October, the fishing grounds are found mostly at the boundary on divergent current system. Several fishing grounds were also found at the outer ring of eddys (Figure 6).

From analysis of available satellite data in figure 6, it can be concluded that currents (divergent, convergent and eddies) are also an parameter important for identification of fishing ground of the pelagic tuna in the Papua waters. These oceanographic parameters were derived from satellite altimeter data (microwave-Radar). Compared to optic data, the detection of these parameters with radar were not influenced by cloud cover. Therefore, utilization of microve data which provides information on currents is proposed to be used together with optic data (visible and thermal), in order to increase the accuracy of fishing ground determination. In the case of unavailability of optic data, the use of Radar data can be used as an alternative. 


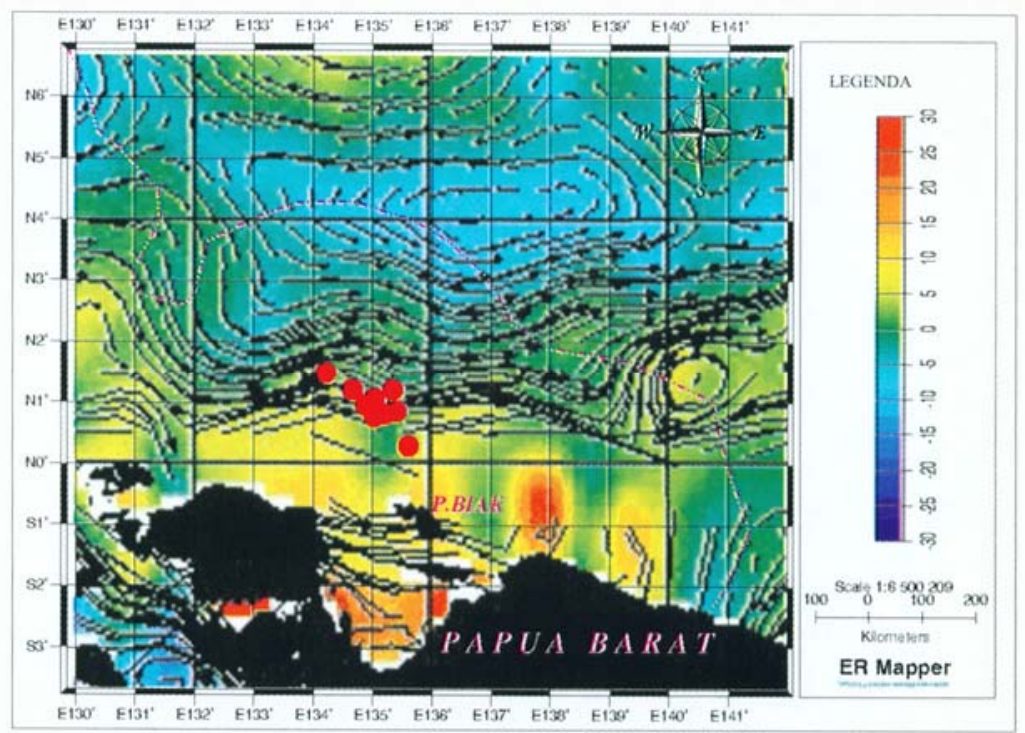

(a) 2 September 2003

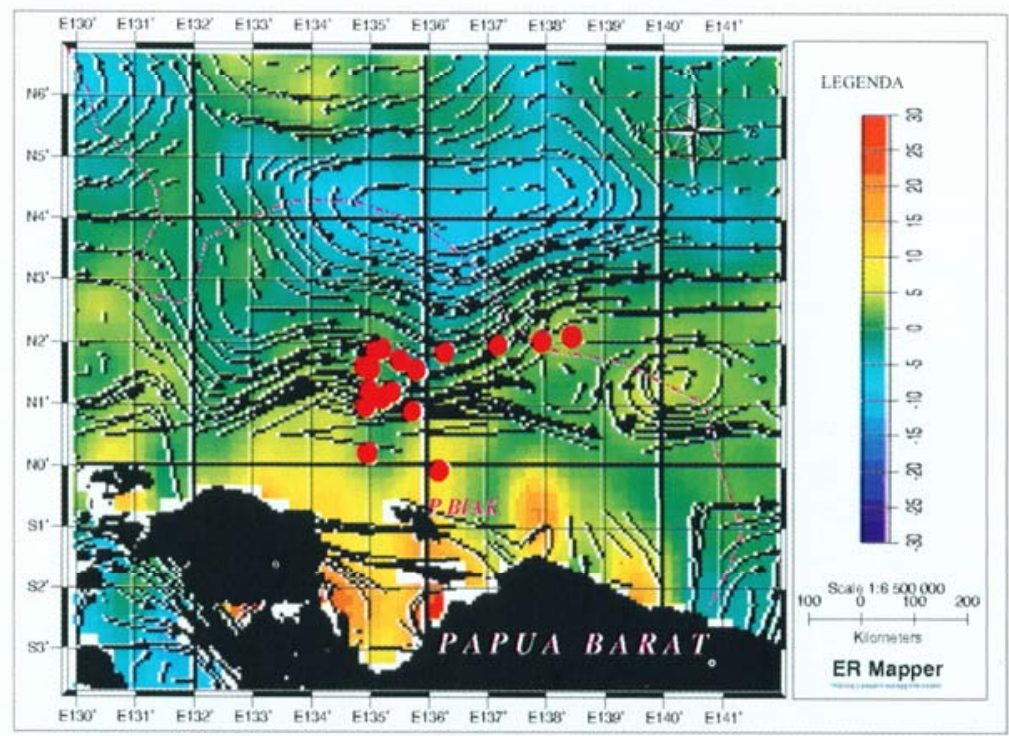

(b) 11 September 2003

Figure 6. The currents derived from Topex POSEIDON and the posisition of pelagic tuna fishing ground from 2 September to 11 September 2003. 


\section{CONCLUSIONS}

Analysis of oceanographic parameters detected from several satellite data and fishing catch data of the North Papua waters showed that the important oceanographic parameters which can be used to identify fishing ground of small pelagic tunas (skipjack and yellow fin tunas) are thermal and chlorophyl-a front, and currents (divergent, convergent and eddies). The combination of these parameters increase the accuracy of fishing ground identification. Thermal (SST), Chlorophyll-a and currents data are derived from optic and microwave (Radar) sensors respectively. Availability of data from sensor optic is limited due to cloud cover, which in this case is very frequent in Papua and Indonesia in general. In the case of cloud cover, where the optic data is not available, Radar data can be used to provide currents information an alternative to determine fishing ground.

The use of Multi-sensor satellite data such as NOAA-17/AVHRR, SeaWIFS and TOPEX POSEIDON can be used integratedly as a promising approach in determination of potential fishing ground of the pelagic tunas in the North Papua waters.

\section{REFERENCES}

Dwivedi, R.M.2000. Ocean Colour as a Tool For Potential Fishing Zone Identification and Forecast. PORSEC 2002. Pre-Conference Training. National Institute of Oceanography. Dona Paula, Goa -403 004, India, p. 17-22.

Gower, J.F.R.1972. Opportunities and Problems in Satellite Measurements of the Sea. UNESCO Tech. Pap. 46, 70 p.

Laevastu, T., and M. L. Hayes. 1981. Fisheries Oceanography and Ecology. Fishing News Books Ltd., 199 p.

Lehodey, P., 2003. SEPODYM Application to Albacore (Thunnus alalunga). Oceanic Fisheries Programme. Noumea, New Caledonia, p. 1-16.

Lewis, A.D., P.O. Williams. 2001. Overview of The Western and Central Pasific Ocean Tuna Fisheries, 2000. Oceanic Fisheries Programme (OFP) Secretariate of the Pasific Community Noumea, New Caledonia, p. 1-31.

LIPI, 1992. Penelitian Potensi Pelagis dan Karakteristik Lingkungan Perairan Utara Irian Jaya. Pusat Penelitian dan Pengembangan Oseanologi. Lernbaga Hmu Pengetahuan Indonesia. Jakarta. 113 p.

Loukos, H. P., L. B. Monfiy., and P. Lehodey. 2003. Potencial Change in Skipjack Tuna (Katsuwonns pelamis) Habitat from a Global Warming Scenario : Modelling Approach and Preliminary Results. Fisheries Oceanography. Blackwell Publishing Ltd., p. 474-482.

Mann, K.H, and J.R.N. Lazier, 1991. Dynamics of Marines Ecosystems. Biological-Physical Interaction in the Ocean. Blackwell Scientific Publication. $446 \mathrm{p}$.

Mc.Millin, L.M., and D.S. Crosby. 1984. Theory and Validation of the Multiple Windows Sea surface Temperature Technique. In Journal of Geophys. Res., No. 89. p. 3655-3661.

Meaden, G.J. and T.D.Chi, 1996. Geographycal Information Systems, Application to Marine Fisheries. FAO Fisheries Technical Paper. No.356 Rome, FAO, 335 p. 
Narain, A. 1993. Chlorophyll Studies Using Remote Sensing. In International Workshop on Applicai of Satelite Remote Sensing for Identifying and Forecasting Potential Fishing Zones in Develop Countries. Hyderabad, India, p. 1-13.

Picarkard, G.L. and W. J. Emery. 1990. Descriptive Physical Oceanography: An Introduction

Robinson, I. 1985. Satelite Oceanography. An Introduction for Oceanographers and Remote Sens Scientists. Ellis Horword Dim: 249 p.

Topex Poseidon Data: http:/www.c.car,col(iradp,edu/ Accessed on October 2003

Triton Bouy Mooring Data: ht.tjK/.;!v^vw..OiieJjioaa;goy,ia.o/j.^di.SPlay. Accessed on October 2003

Seawifs Data: MR^Zs..^.?lfS:.£sfc.nasa.goW Accessed on October 2003

Shixing, H., S. Jianhua., and L. S. Shuxun. 1993. Remote Sensing in Chinese Fisheries. In Intematic Workshop on Application of Satelite Remote Sensing for Identifying and Forecasting Poten Fishing Zones in Developing Countries. Hyderabad, India, p. 1 -4.

Steel, R.G.D. and J.H. Torrie, 1989. Principles and Procedures of Statistics. Second Edition. Me Gi Hill Int.Book Co., 633 p.

Vinogradov, M.E. 1981. Ecosystems of Equatorial Upwelling, In: Analysis of Marine Ecosystei A.R.Longhurst (ed). London: Academic Press, p 69-93

Waas, H.J.D. 2004. Analisis Daerah Potensial Penangkapan Cakalang (Katsuwonus pelamis) ( Madidihang (Thunnnx albacares) di Perairan Utara Papua, Pasifik Barat. Tesis. Seko Pascasarjana IPS, 102 p.

Wenno, L.F., Hadikusuma and Nurhayati, 2001. Hubungan Antara Beberapa Parameter Fis Oseanografi Terhadap Distribusi Kandungan Klorofil-a di Perairan Mamberamo Irian Jaya, Agus 2000. Dalam Perairan Indonesia, Oseanografi, Biologi dan Lingkungan. LP3O-LI Jakarta, p. 9-19. 